\title{
REVIEW OF THE GENUS PHOTOBLEPHARON (ACTINOPTERYGII: BERYCIFORMES: ANOMALOPIDAE)*
}

\author{
Daniel GOLANI ${ }^{1 * *}$, Ronald FRICKE ${ }^{2}$, and Brenda APPELBAUM-GOLANI ${ }^{3}$ \\ ${ }^{1}$ National Natural History Collections and Department of Ecology, Evolution and Behavior, The Hebrew University \\ of Jerusalem, Jerusalem, Israel \\ ${ }^{2}$ Im Ramstal 76, 97922 Lauda-Königshofen, Germany \\ ${ }^{3}$ The Hebrew University of Jerusalem, Jerusalem, Israel
}

Golani D., Fricke R., Appelbaum-Golani B. 2019. Review of the genus Photoblepharon (Actinopterygii: Beryciformes: Anomalopidae). Acta Ichthyol. Piscat. 49 (1): 33-41.

\begin{abstract}
The flashlight fishes of the genus Photoblepharon (Family: Anomalopidae) are herein reviewed, in order to clarify their taxonomy. The genus includes two species Photoblepharon palpebratum (Boddaert, 1781) from the eastern Indian Ocean and the western Pacific Ocean and Photoblepharon steinitzi Abe et Haneda, 1973 from the Red Sea, Oman, and western Indian Ocean. The study was initiated because the holotype of P. steinitzi was lost. Neotypes for these two species are designated due to the loss of the type specimens of both species and problems with the identity of the two species. A key for these species is provided. Several biological, ecological and other uses of the light organ are given for P. steinitzi from the Gulf of Aqaba. Observations in nature and experiments in the aquarium are described.
\end{abstract}

Keywords: flashlight fish, Photoblepharon palpebratum, Photoblepharon steinitzi, taxonomy

\section{INTRODUCTION}

The flashlight fishes of the family Anomalopidae are a group of marine fishes characterized by a large luminous organ which is situated below the eye, with a rotational and/or shutter mechanism for controlling light emission (Nelson 2006). They are distributed in warm waters of the Indo-West Pacific, the eastern Pacific, and the western Atlantic. The family comprises 6 genera with 9 species (Nelson 2006, Ho and Johnson 2012).

The genus Photoblepharon was first described by Weber (1902) for the western Pacific Sparus palpebratus Boddaert, 1781, a species of flashlight fish with a single dorsal fin and a fixed (not rotating) luminous organ. Abe and Haneda (1973) added a new subspecies, P. palpebratus steinitzi, which was later raised to species level by McCosker and Rosenblatt (1987), who reviewed the family and found several distinguishing characters between the two species, including the pelvic-fin ray number, the number of spinules on the posterior margin of the maxilla, and the colouration of the opercle.

However, there has been some confusion concerning the identity of the two species in the literature, and both species are devoid of type specimens. The purpose of this current paper is to review the species of Photoblepharon, and to stabilize the prevailing usage of the species names Sparus palpebratus Boddaert, 1781 and Photoblepharon steinitzi Abe et Haneda, 1973 (in the sense of McCosker and Rosenblatt 1987) by neotype designations.

\section{METHODS}

Count and measurement methods follow McCosker and Rosenblatt (1987). The last soft ray in the dorsal and anal fin is split at its base, but counts as a single ray. The standard length is abbreviated SL, the head length HL. Collection acronyms follow Fricke and Eschmeyer (2018).

The following abbreviations were used: the Natural History Museum, London, UK (BMNH), the California Academy of Sciences, San Francisco, USA (CAS), the Hebrew University Fish Collection, Jerusalem, Israel (HUJ), the Steinhart Museum of Natural History, Tel Aviv University, Tel Aviv, Israel (SMNHTAU), the Staatliches Museum für Naturkunde Stuttgart, Germany (SMNS), and the University Museum, University of Tokyo, Tokyo, Japan (ZUMT).

Comparative material. Anomalops katoptron (Bleeker, 1856): BMNH 1890.9.1.8 (1), Vanuatu; SMNS 24078 (1), Philippines, Mindanao.

\footnotetext{
" Zoo-Bank registration: urn:1sid:zoobank.org:pub:DACA8E01-6C04-44CB-B964-5D2092FE9342.

** Correspondence: Dr Daniel Golani, National Natural History Collections and Department of Ecology, Evolution and Behaviour, The Hebrew University of Jerusalem, 91904 Jerusalem, Israel, e-mail: (DG) dani.golani@mail.huji.ac.il, (RF) ronfricke@web.de, (BAG)brendag@savion.huji.ac.il.
} 


\section{RESULTS}

\section{Family ANOMALOPIDAE}

\section{Photoblepharon Weber, 1902}

Photoblepharon Weber, 1902; Weber 1902: 108 (type species: Sparus palpebratus Boddaert, 1781; type by monotypy), Weber and de Beaufort 1929: 226, McCosker 1986: 413, McCosker and Rosenblatt 1987: 158, Johnson and Rosenblatt 1988: 71, Rosenblatt and Johnson 1991: 333, Kotlyar 1996: 214, Baldwin et al. 1997: 377, Paxton and Johnson 1999: 2213, Paxton et al. 2006: 764.

Diagnosis. Moderately deep body with slightly rounded dorsal and ventral contours. Rather long caudal peduncle. Blunt head with short snout. Anterior and posterior nostrils close to each other. Eyes large; elliptical light organ under eye, which cannot be rotated ventrally into pocket, but with black shutter that lifts to cover organ. Lateral line slightly arched above pectoral fin. Dorsal fin single, triangular, with 2 small spines and 17-19 rays. Anal fin with 2 small spines and 14-15 rays. Caudal fin forked. Pectoral fin with 16-18 rays and pelvic fin with 6-7 rays. Key to the species of Photoblepharon Weber, 1902

1a. Conspicuous white spot at upper corner of opercle, covering naked area; pelvic-fin rays 7; rear tip of maxilla heavily sculptured with 23 or more small denticles

Photoblepharon palpebratum (Boddaert, 1781)

1b. Naked area at upper corner of opercle with a small elongate, not obvious white spot; pelvic-fin rays 6; rear tip of maxilla sculptured with 18 or less small denticles

Photoblepharon steinitzi Abe et Haneda, 1973

Photoblepharon palpebratum (Boddaert, 1781) (Fig. 1) Sparus palpebratus Boddaert, 1781; Boddaert 1781: 55, pl. 4, figs. 1-2 [plate not seen] (Amboina/Ambon, Maluku, Indonesia), Gmelin 1789: 1274.

Kurtus palpebratus: Bloch and Schneider 1801: 164.

Bodianus palpebratus: Anonymous 1832: 109 (part), Desmarest 1876: 348 (part).

Heterophthalmus palpebratus: Bleeker 1858: 253 (Amboina/Ambon, Maluku, Indonesia), Vorderman 1900: 72 (Banda, Maluku, Indonesia).

Photoblepharon palpebratus: Weber 1902: 108, Steche 1909: 354, pl. 19, fig. 2 (Amboina/Ambon, Maluku, Indonesia), Weber 1913: 191, figs. 50-51 (Banda, Maluku, Indonesia), Harvey 1922: 45, Weber and Beaufort 1929: 227, figs. 66-67 (Banda, Ambon, Indonesia), Harvey 1940: 31, Fowler 1959: 131, Haneda and Tsuji 1971a: 143, Haneda and Tsuji 1971b: 18, Meyer-Rochow 1976: 325, Zehren 1979: 102, Meyer-Rochow 1981: 419, McCosker 1982: 98, Meyer-Rochow et al. 1982: 66, Haygood et al.1984: 249, Randall 1986: 182, fig. 10 (Kwajalein, Marshall Islands), Kailola 1987: 172 (Port Moresby, Papua New Guinea), McCosker and Rosenblatt 1987: 158, figs. 2B, 3 B (Cebu and Mindoro, Philippines; Enewetak, Marshall Islands; Oroluk, Caroline Islands; Rarotonga, Cook Islands; Queensland, Australia; Madang and Port Moresby, Papua New Guinea; etc.), Randall and Randall 1987: 294, Rivaton et al. 1990:
22 (New Caledonia), Randall 1995: 93, Kotlyar 1996: 215, fig. 106, Randall et al. 1997: 498, fig. (Coral Sea), Myers 1999: 78, fig. 2 (Palau, Caroline Islands, southern Marianas [?], etc.), Paxton and Johnson 1999: 2213, Laboute and Grandperrin 2000: 150, fig. (New Caledonia), Paxton and Johnson in Randall and Lim 2000: 601 (South China Sea), Allen and Adrim 2003: 26 (Bali and Flores, Indonesia), Randall 2005: 85 (Papua New Guinea, Cook Islands, etc.), Fricke and Kulbicki 2006: 322, Paxton et al. 2006: 764 (Coral Sea Islands Territory and Queensland, Australia), Fricke and Kulbicki 2007: 366, Allen and Bailey 2011: 101 (Phoenix Islands, Kiribati), Anonymous 2011: 13, Allen and Erdmann 2012: 167 (Kalimantan, Indonesia; Sabah, Malaysia; etc.), Koeda et al. 2014: 27 (Okinawa, Ryukyu Islands, Japan), Laboute and Grandperrin 2016: 166, fig. (New Caledonia). Photoblepharon palpebratus palpebratus: Schwarzhans 1980: 110, fig. 359 (otolith), Fricke 1999: 125.

Photoblepharon palpebratum: Dor 1984: 70, Allen and Erdmann 2009: 594 (Birds Head Peninsula, Papua, Indonesia), Fricke et al. 2011: 372 (Grande Terre, New Caledonia), Tan et al. 2014: 415, fig. 25 (Christmas Island, eastern Indian Ocean), Hellinger et al. 2017: 2.

Photoblepharon palpebratus: Myers and Donaldson 2003: 612 (Mariana Islands).

Neotype (as designated below): CAS 82480, $72.6 \mathrm{~mm}$ SL, Western Pacific, Banda Sea, Indonesia Maluku, Pulau Lucipara, ca. $5^{\circ} 30^{\prime} \mathrm{S}, 127^{\circ} 32^{\prime} \mathrm{E}$, J.E. McCosker et al., 24 Sept. 1992.

Other material examined. CAS 58145, 2 specimens, 66.0, $72.2 \mathrm{~mm}$ SL, South Pacific Ocean, Cook Islands, Rarotonga, off Avarua Pass, $21^{\circ} 12^{\prime} 14^{\prime \prime} \mathrm{S}, 159^{\circ} 46^{\prime} 30^{\prime \prime} \mathrm{W}, 45$ feet (13.7 m) depth, B. Hill et al., 20 Apr. 1982; CAS uncat. (ex 82480), 4 specimens, 62.9, 68.4, 69.5, $78.7 \mathrm{~mm}$ SL, same data as CAS 82480.

Diagnosis. Body moderately deep, body depth $32.5 \%$ $43.5 \%$ of SL. Caudal-peduncle length $26.8 \%-30.6 \%$ of SL, caudal-peduncle depth $12.4 \%-13.2 \%$ of SL. Head length $32.3 \%-35.6 \%$ of SL, snout length $11.2 \%-18.2 \%$ of HL. Anterior and posterior nostrils close to each other, situated anterior to orbit. Dorsal profile of head nearly straight to slightly convex. Rear tip of maxilla sculptured with 23-30 denticles. Eye large, its horizontal diameter $38.5 \%-46.5 \%$ of HL. Light organ elliptical, its length $45.5 \%-49.4 \%$ of HL, it depth $15.2 \%-21.2 \%$ of HL. Gill rakers $5+16-20$. Lateral line slightly arched above pectoral fin; lateral-line scales 28-38. Dorsal fin triangular, with 2 small spines and 17-20 rays, the 6th-8th or 9 th rays being longest. Anal fin with 2 small spines and 14-15 rays, the 4 th ray being longest. Pectoral fin with $17-18$ rays and pelvic fin with 7 rays.

Description of the Neotype. Moderately deep body (42.2\% of SL) with slightly rounded dorsal and ventral contours. Rather long caudal peduncle, its length $29.2 \%$ of SL and its depth $12.7 \%$ of SL. Blunt head $(35.0 \%$ of SL) with short snout ( $15.0 \%$ of HL). Anterior and posterior nostrils close to each other, situated anterior to orbit. Dorsal profile of head nearly straight. Lower jaw slightly oblique, reaching back to vertical of middle of eye. Bands of small conical teeth in upper jaw, also on outer edge and visible when mouth is 
closed. Small shallow knob-like bulge on anterior of upper jaw with small teeth spaced at symphysis. At the anterior of lower jaw knob-like enlargement with larger teeth having gap at symphysis, visible when mouth is closed, followed by narrow bands of small teeth arranged in irregular rows. Rear tip of maxilla sculptured with 25 denticles. Eye large, its horizontal diameter $41.4 \%$ of HL. Under eye is an elliptical light organ, its length $47.5 \%$ of HL and depth $15.6 \%$ of HL. Gill rakers $5+16$. Lateral line slightly arched above pectoral fin; lateral-line scales 34. Dorsal fin triangular, with 2 small spines and 19 rays, 6th-8th rays being longest. Anal fin with 2 small spines and 14 rays, 4 th ray being longest. Caudal fin forked. Pectoral fin with 18 rays and pelvic fin with 7 rays. Colouration. Randall et al. (1997: 498) and Laboute and Grandperrin (2000: 150; 2016: 166) provided colour photographs of live specimens. Body and fins are blackish. Lateral line and the posterior edge of operculum white to light blue. Large white spot on dorsal corner of opercle. The light organ is white. Colour of the preserved neotype is light brown, the pectoral fin dark brown, white

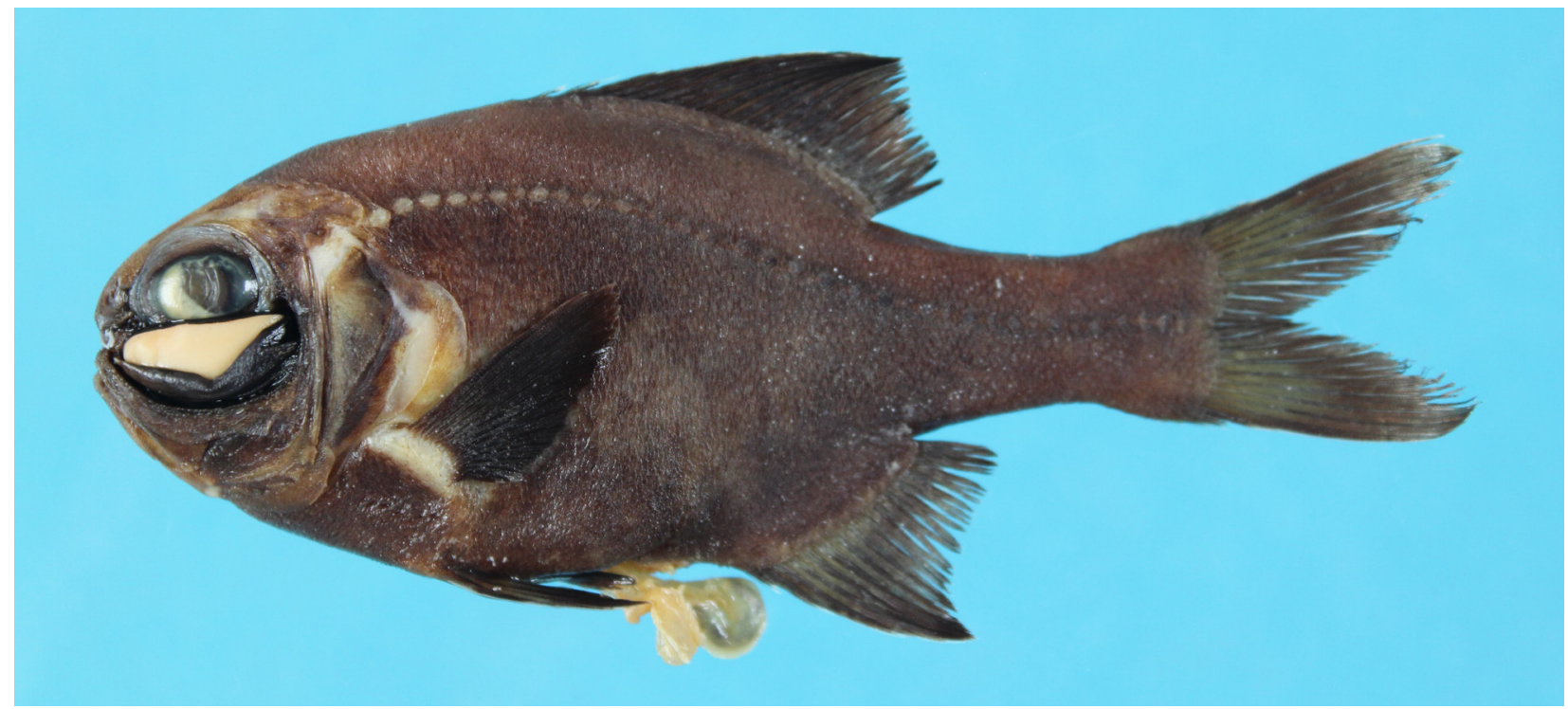

Fig. 1. Photoblepharon palpebratum (Boddaert, 1781), neotype, CAS 82480, $72.6 \mathrm{~mm}$ SL, Banda Sea, Indonesia, Maluku, Pulau Lucipara (Photograph: D. Golani)

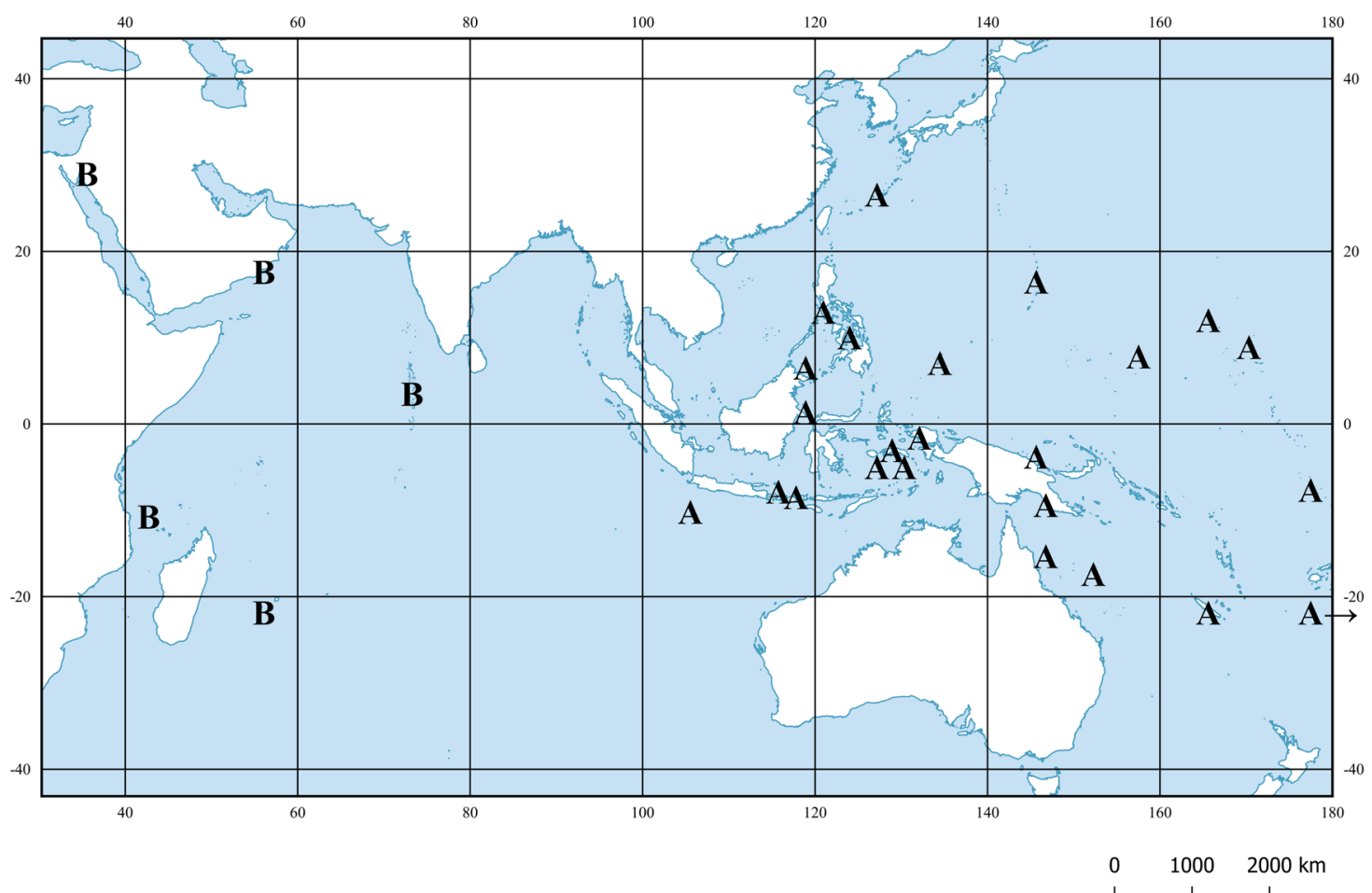

Fig. 2. Geographical distribution of Photoblepharon palpebratum (A) and Photoblepharon steinitzi (B) 
spot on dorsal corner of opercle. The light organ is white surrounded by black tissue (Fig. 1).

Distribution. Christmas Island; Ryukyu Islands (Okinawa); Indonesia (Kalimantan; Bali; Flores; Maluku: Banda, Pulau Lucipara, Ambon; West Papua), Malaysia (Sabah), Philippines (Cebu; Mindoro), Mariana Islands, Palau, Federated States of Micronesia (Oroluk, Caroline Islands), Marshall Islands (Kwajalein; Enewetak), Papua New Guinea (Madang; Port Moresby), Australia (Queensland; Coral Sea Islands Territory), New Caledonia (Grande Terre), Kiribati (Phoenix Islands), Cook Islands (Rarotonga) (Fig. 2).

Remarks. Boddaert (1781) described Sparus palpebratus based on two specimens, one in the collection of Gaubius, the other in his own collection, said to occur near Amboina (Ambon, Indonesia). One of the specimens had no locality, the other locality was doubtful, as at the time specimens were collected by sailors or medical doctors from fish markets throughout the region, and brought to the Netherlands on tedious voyages where they could easily have been mixed up and confused, for example with material from the Mascarenes. The description of Sparus palpebratus is insufficient to distinguish between the two species of the genus or the co-occurring Anomalops katoptron (Bleeker, 1856), and the plate is not available in any of the three online versions of volume 2 of the Neue Nordische Beyträge zur physikalischen und geographischen Erd-und Völkerbeschreibung, Naturgeschichte und Oekonomie we could detect, so it may not have been published. The six pelvic fin rays described by Boddaert (1781) rather point to Photoblepharon steinitzi than to P. palpebratum. The authors of the Catalog of Fishes online (Fricke et al. 2018) have been unable to detect any of the two syntypes over a period of nearly 40 years of intensive search of fish types, so they are considered to be lost. In order to stabilize the present usage of the name Photoblepharon palpebratum (Boddaert, 1781), we hereby designate the specimen CAS 82480 (described above) as the neotype of Sparus palpebratus Boddaert, 1781. The neotype originates from the Lucipara Islands in the Banda Sea, which are as close as possible to the assumed original type locality.

Arecord of Anomalops palpebratus (non Boddaert, 1781) of Ogilby (1890: 70, Vanuatu) and Reuvens (1897: 127, Sulawesi, Indonesia) is based on misidentified specimens of Anomalops katoptron (Bleeker, 1856); this misidentification is confirmed by the authors who re-examined one of the specimens used by Ogilby (BMNH 1890.9.1.8, collected in the Bay of Bengal according to the label, but in Vanuatu according to the BMNH fish catalogue entry).

Photoblepharon steinitzi Abe et Haneda, 1973 (Fig. 3) Photoblepharon sp.: Fridman 1972: 1.

Photoblepharon palpebratus steinitzi Abe et Haneda, 1973; Abe and Haneda 1973: 57, Godeaux 1979: 169, fig. 8, Bauchot et al. 1982: 390, Scharzhans 1980: 110, fig. 358 (otolith), McCosker 1986: 413 (Grand Comoro Island), Fricke 1999: 125 (Réunion), Letourneur et al. 2004: 209. Photoblepharon palpebratus (non Boddaert, 1781): McCosker and Lagios 1975: 1, Morin et al. 1975: 74, Randall 1983: 36, Debelius 1999: 60.
Photoblepharon palpebratum steinitzi: Dor 1984: 70, Debelius 1993: 63, Fricke 1999: 125.

Photoblepharon steinitzi: McCosker and Rosenblatt 1987: 161 (Israel; Egypt; Grande Comore Island), Randall and Anderson 1993: 9 (Maldives), Goren and Dor 1994: 17, Randall, 1995: 93 (southern Oman), Kotlyar 1996: 216, Randall et al. 1997: 498, Debelius 1998: 32 (Sharm el Sheikh, Egypt), Manilo and Bogorodsky 2003: S100, Lieske and Myers 2004: 49 (Mövenpick Resort, Soma Bay, Egypt), Randall 2005: 85, Fricke et al. 2009: 32, Golani and Bogorodsky 2010: 18, Hellinger et al. 2017: 2, Jawad et al. 2018: 71, fig.

Neotype. (as designated below): HUJ 20546, $66.6 \mathrm{~mm}$ SL, Gulf of Aqaba, 1975.

Other material examined. BMNH 1875.12.8.1, 1 specimen, $73.3 \mathrm{~mm}$ SL, Comoros, Grande Comore Island, north of Itsandra, $11^{\circ} 39^{\prime} 19^{\prime \prime} \mathrm{S}, 43^{\circ} 15^{\prime} 42^{\prime \prime} \mathrm{E}$, J.E. McCosker, 16 Feb. 1975; CAS 35113, 1 specimen, $65.3 \mathrm{~mm}$ SL, Comoros, Grande Comore Island, north of Itsandra,

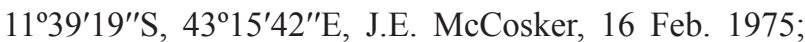
HUJ 20550, 2 specimens, 66.7, $68.6 \mathrm{~mm} \mathrm{SL}$, Gulf of Aqaba, 1975; SMNHTAU 7059, 61.2 mm SL, Eilat, Gulf of Aqaba. 20 Nov. 1972.

Diagnosis. Body moderately deep, body depth $34.8 \%-$ $47.9 \%$ of SL. Caudal-peduncle length $21.6 \%-32.7 \%$ of SL, caudal-peduncle depth $12.1 \%-13.6 \%$ of SL. Head length $33.2 \%-38.0 \%$ of SL, snout length $12.9 \%-16.3 \%$ of HL. Anterior and posterior nostrils close to each other, situated at level of upper three quarters of orbit. Dorsal profile of head slightly convex. Rear tip of maxilla sculptured with 11-18 denticles. Eye large, its horizontal diameter $38.4 \%-44.6 \%$ of HL. Light organ elliptical, its length $43.8 \%-52.1 \%$ of HL, it depth $14.6 \%-18.3 \%$ of HL. Gill rakers $5+17-22$. Lateral line slightly arched above pectoral fin; lateral-line scales 31-34. Dorsal fin triangular, with 2 small spines and 16-18 rays, 6th-8th rays being longest. Anal fin with 2 small spines and 13-15 rays, 3rd ray being longest. Pectoral fin with 16-17 rays and pelvic fin with 6 rays.

Description of the Neotype. Moderately deep body (34.8\% of SL) with slightly rounded dorsal and ventral contours. Rather long caudal peduncle, its length $21.6 \%$ of SL and its depth $12.9 \%$ of SL. Blunt head, head length $34.8 \%$ of SL, with short snout (12.9\% of HL). Anterior and posterior nostrils close to each other, situated at level of the upper three quarters of orbit. Dorsal profile of head slightly convex. Lower jaw strongly oblique, reaching posteriorly to vertical of middle of eye. Bands of small conical teeth in the upper jaw, also on the outer edge and visible when mouth is closed. Small shallow knob-like bulge at front of upper jaw with small teeth spaced at the symphysis. At front of lower jaw knob-like enlargement with larger teeth having gap at symphysis, visible when mouth is closed, follow by narrow bands of small teeth arranged in irregular rows. Rear tip of maxilla sculptured with 15 denticles. Eye large, its horizontal diameter 38.4\% of HL. Under eye is elliptical light organ, its length $46.1 \%$ of HL and depth $15.1 \%$ of HL. Gill rakers $5+20$. Lateral line slightly arched above pectoral fin; lateral-line scales 
32. Dorsal fin triangular, with 2 small spines and 17 rays, 6th-8th rays being longest. Anal fin with 2 small spines and 14 rays, 3rd ray being longest. Caudal fin forked. Pectoral fin with 16 rays and pelvic fin with 6 rays.

Colouration. Randall (1983: 36), Debelius (1998) and Lieske and Myers (2004) provided colour photographs of live specimens. Body and fins are blackish. Lateral line and the posterior edge of operculum light blue. Small, elongate white spot at upper corner of opercle. The light organ is white. Margins of dorsal, anal and caudal fins bright blue, leading edge of pelvic fins bright blue. Colour of the preserved neotype is light brown, the pectoral fin dark brown. The light organ is white surrounded by black tissue (Fig. 1).

Distribution. Red Sea (Gulf of Aqaba: Israel, Egypt; ElQusayr, Egypt), Oman (south coast), Comoros (Grande Comore), Réunion, Maldives (Fig. 2).

Remarks. In 1973, Abe and Haneda described Photoblepharon palpebratus steinitzi, as a new subspecies of flashlight fish from the Gulf of Eilat (Gulf of Aqaba), Red Sea, based on three specimens, all from the Hebrew University Fish Collection (HUJ). The holotype was HUJ-F 5368a and the paratypes were HUJ-F 5131 and HUJ-F 5368 b. Several years later, Randall (1983) did not agree with the division into two subspecies. However, even later McCosker and Rosenblatt (1987) agreed with Abe and Haneda (1973) and elevated Photoblepharon steinitzi to the specific level, based on the different number of pelvic fin rays, the shape of the sculpturing on the rear tip of the maxilla and the supramaxilla and some colour patterns.

Since the 1980s one of the authors (D.G.) has tried to locate the three types specimens, to no avail. This led to the conclusion that the type specimens have been lost (Golani 2006: 23). The second author (R.F.) also enquired about materials, which were sent on loan to the late T. Abe (ZUMT), and was informed by K. Mochizuki (personal communication, 1998) that unfortunately these materials were lost (for a biography of T. Abe see Arai 1997). McCosker and Rosenblatt (1987) identified some western Indian Ocean populations as $P$. steinitzi, while eastern Indian Ocean populations were attributed to $P$. palpebratum. Apparently erroneously, Debelius (1999) restricted $P$. steinitzi to the Red Sea and considered the Indian Ocean populations as $P$. palpebratum (non Boddaert, 1781).

Photoblepharon steinitzi is characterised by the pelvic fin rays usually I, 5 (versus usually I, 6 in P. palpebratum), and the anteriormost lateral-line pore preceded by a small, not obvious white spot on dorsal corner of opercle (versus preceded by a bright white spot on dorsal corner of opercle in P. palpebratum).

The specimen HUJ 20546 (66.6 mm SL, see Fig. 3) is hereby designated as the neotype of Photoblepharon steinitzi Abe et Haneda, 1973 (see the remarks above).

The original holotype (HUJ F5368a) was collected at Ras Burqa [near Nuweiba], Gulf of Aqaba, Red Sea. The neotype likewise originates from the Gulf of Aqaba, Red Sea.

\section{DISCUSSION}

The biology and ecology of the species of the genus Photoblepharon have fascinated researchers for many years. Like other members of the family, P. steinitzi is a nocturnal species, active mainly on moonless nights. During the day, it hides in caves and crevices, usually in small groups, up to 100 fish, at depths of $50 \mathrm{~m}$ to the surface (Fridman 1972). Photoblepharon steinitzi is equipped with a bean-shaped luminous organ under each eye. The light is produced by symbiotic bacteria, which are species-specific, as a result of a metabolic process (McCosker 1977). The manner in which the newly hatched fish acquire the symbiotic bacteria is not clear. All attempts to extract and culture the bacteria have failed. Nevertheless the bacteria continue to glow several hours after removal from the fish. The light organ can be switched off by pulling a black membrane over it (McCosker 1977). The light organ and the ability to turn it off serve the fish for several purposes. The light attracts various organisms, mainly zooplankton; this phenomenon

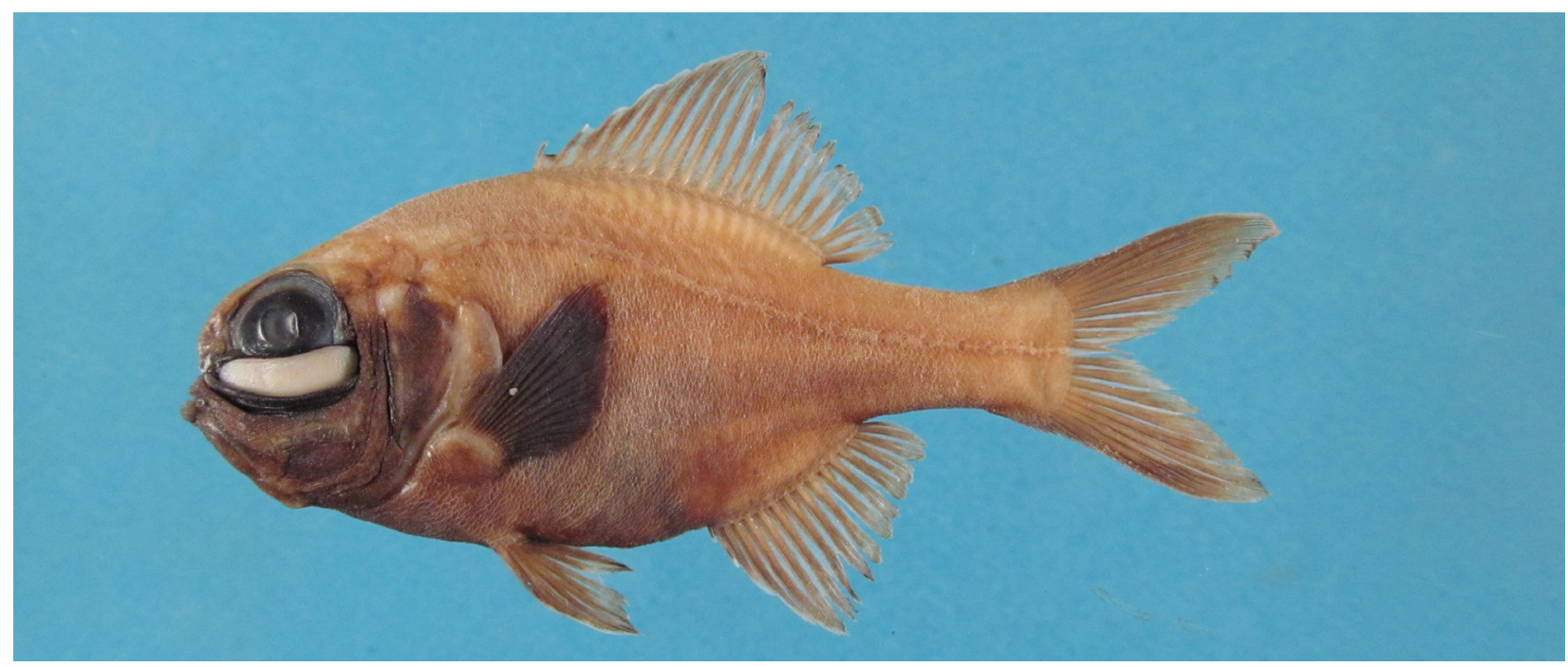

Fig. 3. Photoblepharon steinitzi Abe et Haneda, 1973, neotype, HUJ 20546, 66.6 mm SL, Gulf of Aqaba (Photograph: D. Golani) 
is known as phototactism. Photoblepharon steinitzi feeds mainly on Mysidacea, Cumacea, Amphipoda, and, to a lesser extent, fish larvae, polychaetes and some benthic crustaceans, their proportion in stomach contents was much higher than in the environment (Sagi unpublished*). Sagi (unpublished*) reported a series of experiments on Photoblepharon in aquaria and showed that they prey selectively.

The switching on and off of the light organ also assists the fish in escaping predators. When threatened, the fish moves in a zigzag pattern, while flashing its light, which confuses the predator (Clark 1978). In addition, the blinking of several fish coordinated in a group distracts the predator and makes it difficult to concentrate on specific individual fish (McCosker 1977). The rate of blinking the light organ on and off also constitutes communication between fishes including intra-specific recognition and searching for a potential mate (Sagi unpublished*).

The light organ is apparently fully developed in adult specimens only; larvae of the Atlantic Ocean species Kryptophanaron alfredi Silvester et Fowler, 1926 are lacking an obvious light organ (Baldwin and Johnson 1995). McCosker (1982) reported an allometric growth of the light organ relative to the head length in subadult and adult specimens of anomalopids. Though larvae and juveniles of the genus Photoblepharon are still unknown, the size and allometric growth might be similar in that genus.

The spawning season of Photoblepharon steinitzi in the Gulf of Aqaba extends from July to September. Each batch consists of ca. 600 eggs; most likely there are several batches per spawning season (Sagi unpublished). The larvae have a quite brief planktonic stage of 12-14 h. Juveniles inhabit rocky substrate or hide near corals, mainly of the genus Acropora. The juveniles join the group only after reaching adult size (Sagi unpublished). The smallest specimen collected in the Gulf of Aqaba was $10 \mathrm{~mm}$ and externally had an adult shape with a complete and presumably functioning light organ.

Six individuals of Photoblepharon steinitzi are kept in the Underwater Observatory Marine Park in Eilat, Israel; some of these have been there for at least 20 years. Two of these fish have ceased to have functioning light organs (A. Levi, personal communication).

\section{ACKNOWLEDGEMENTS}

We are grateful to the following persons and institutes for the specimens loan: James Maclaine (BMNH), David Catania (CAS), and Menachem Goren (SMNHTAU). We thank Dr G. Sagi for access to his unpublished MSc thesis.

\section{REFERENCES}

Abe T., Haned [sic, Haneda] Y. 1973. Contributions to the knowledge of the Red Sea No. 50. Description of a new fish of the genus Photoblepharon (family
Anomalopidae), from the Red Sea. Bulletin of the Sea Fishery Research Station, Haifa 60: 57-62.

Allen G.R., Adrim M. 2003. Coral reef fishes of Indonesia. Zoological Studies 42 (1): 1-72.

Allen G.R., Bailey S. 2011. Reef fishes of the Phoenix Islands, central Pacific Ocean. Atoll Research Bulletin 589: 83-118. DOI: 10.5479/si.00775630.589.83

Allen G.R., Erdmann M.V. 2009. Reef fishes of the Bird's Head Peninsula, West Papua, Indonesia. Check List 5 (3): 587-628. DOI: 10.15560/5.3.587

Allen G.R., Erdmann M.V. 2012. Reef fishes of the East Indies. Volume I. Tropical Reef Research, Perth: $\mathrm{i}-\mathrm{X}+$ $1-424+$ end note.

Anonymous 2011. Phoenix Islands Protected Area, Kiribati. List of species. Kiribati: 1-39.

Arai R. 1997. Memories of Dr. Tokiharu Abe (19111996). Ichthyological Research 44 (1): 98-99.

Baldwin C.C., Johnson G.D. 1995. A larva of the Atlantic flashlight fish, Kryptophanaron alfredi (Beryciformes: Anomalopidae), with a comparison of beryciform and stephanoberyciform larvae. Bulletin of Marine Science 56 (1): 1-24.

Baldwin C.C., Johnson G.D., Paxton J.R. 1997. Protoblepharon rosenblatti, a new genus and species of flashlight fish (Beryciformes: Anomalopidae) from the tropical South Pacific, with comments on anomalopid phylogeny. Proceedings of the Biological Society of Washington 110 (3): 373-383.

Bauchot R., Diagne M., Ridet J. 1982. The brain of Photoblepharon palpebratus steinitzi (Pisces, Teleostei, Anomalopidae). Journal für Hirnforschung 23 (4): 390-404.

Bleeker P. 1858. Nog iets over het geslacht Heterophthalmus Blkr. [Something about the genus Heterophthalmus Blkr.] Natuurkundig Tijdschrift voor Nederlandsch Indië 16 (2): 253-255. [In Dutch.]

Bloch M.E., Schneider J.G. 1801. M.E. Blochii, doctoris medicinae berrolinensis, et societatibus literaris multis adscripti, SYSTEMAICHTHYOLOGIAE ICONIBUS CX ILLUSTRATUM. Post obitum auctoris opus inchoatum absolvit, correxit, interpolavit Jo. Gottlob Schneider, Saxo. Berolini, Sumtibus Austoris Impressum et Bibliopolio Sanderiano Commissum. Berlin, Kingdom of Prussia. i-1x + 1-584, pls. 1-110. [In Latin.] DOI: 10.5962/bhl.title.5750

Boddaert P. 1781. Beschreibung zweyer merkwürdiger Fische. Neue Nordische Beyträge zur physikalischen und geographischen Erd- und Völkerbeschreibung, Naturgeschichte und Oekonomie, St. Petersburg and Leipzig 2: 55-57, pls. 2, 4. [Plates not seen.]

Clark E. 1978. Flashlight fish of the Red Sea. National Geographic 154 (5): 719-728.

Debelius H. 1993. Fischführer Indischer Ozean. Malediven, Sri Lanka, Mauritius, Madagaskar, Ostafrika, Seychellen, Arabisches Meer, Rotes Meer. Tetra-Verlag, Berlin, Germany: 321 pp. 
Debelius H. 1998. Red Sea reef guide/Egypt, Israel, Jordan, Sudan, Saudi Arabia, Yemen, Arabian Peninsula (Oman, UAE, Bahrain). IKAN Underwasserarchiv, Frankfurt am Main, Germany: 319 pp.

Debelius H. 1999. Indian Ocean reef guide. Maldives, Sri Lanka, Thailand, South Africa, Mauritius, Madagascar, East Africa, Seychelles. IKAN Underwasserarchiv, Frankfurt am Main, Germany: 321 pp.

Desmarest A.-G. 1876. Histoire naturelle de Lacépède, comprenant des cétacés, les quadrupèdes ovipares, les serpents et les poissons. Nouvelle édition. Tome deuxième. Furné, Jouvet et Cie, Paris: 1-647, pls. 1-36.

Dor M. 1984. Checklist of the fishes of the Red Sea. CLOFRES. Israel Academy of Sciences and Humanities, Jerusalem: i-xxii, map + 1-437.

Fowler H.W. 1959. Fishes of Fiji. Government of Fiji, Suva, Fiji: 1-670.

Fricke R. 1999. Fishes of the Mascarene Islands (Réunion, Mauritius, Rodriguez). An Annotated Checklist with Descriptions of New Species. Theses Zoologicae Vol. 31. Koeltz Scientific Books, Koenigstein, Germany: iviii $+1-759$.

Fricke R., Eschmeyer W.N. 2018. Guide to fish collections. Catalog of fishes; California Academy of Sciences, San Francisco, USA. [Accessed on 26 September 2018.] http://researcharchive.calacademy. org/research/ichthyology/catalog/collections.asp

Fricke R., Eschmeyer W.N., van der Laan R. (eds.) 2018. Catalog of fishes: Genera, species, references. California Academy of Sciences, San Francisco, USA. [Accessed on 26 September 2018.] http://researcharchive.calacademy.org/research/ ichthyology/catalog/fishcatmain.asp.

Fricke R., Kulbicki M. 2006. Checklist of the shore fishes of New Caledonia. Pp. 313-357, pls. 15/1 and 15/2. In: Payri C.E., Richer de Forges B. (eds.) Compendium of marine species from New Caledonia. Documents Scientifiques et Techniques, Institut de Recherche pour le Développement Nouméa II 7: i-xiii + 10-391, 19 pls.

Fricke R., Kulbicki M. 2007. Checklist of the shore fishes of New Caledonia. 2nd edn. Pp. 357-401, pls. 15/1 and 15/2. In: Payri C.E., Richer de Forges B. (eds.) Compendium of marine species from New Caledonia. 2nd edition. Documents Scientifiques et Techniques, Institut de Recherche pour le Développement Nouméa II 7 (2): 1-435, 19 pls

Fricke R., Kulbicki M., Wantiez L. 2011. Checklist of the fishes of New Caledonia, and their distribution in the southwest Pacific Ocean (Pisces). Stuttgarter Beiträge zur Naturkunde A, Neue Serie 4: 341-463.

Fricke R., Mulochau T., Durville P., Chabanet P., Tessier E., Letourneur Y. 2009. Annotated checklist of the fish species (Pisces) of La Réunion, including a Red List of threatened and declining species. Stuttgarter Beiträge zur Naturkunde A, Neue Serie 2: 1-168.

Fridman D. 1972. Note on the ecology of a new species of Photoblepharon (Pisces, Anomalopidae) from the
Gulf of Elat (Aqaba). Scientific Newsletter, The Heinz Steinitz Marine Biology Laboratory, Eilat 2: 1-2.

Gmelin J.F. 1789. Caroli a Linné, [...] Systema Naturae per regna tria naturae, secundum classes, ordines, genera, species; cum characteribus, differentiis, synonymis, locis. Editio decimo tertia, aucta, reformata. Tom. I. Pars III. G.E. Beer, Lipsia, Saxony: 1033-1516. [Fishes on pp. 1126-1516.] DOI: 10.5962/ bhl.title.36932

Godeaux J. 1979. Le Golfe d'Élat et son intérêt biologique. Les Naturalistes Belges 60: 165-175.

Golani D. 2006. An annotated list of types in the Hebrew University Fish Collection. Haasiana 3: 20-40.

Golani D., Bogorodsky S.V. 2010. The fishes of the Red Sea-Reappraisal and updated checklist. Zootaxa 2463 (1): 1-135. DOI: 10.11646/zootaxa.2463.1.1

Goren M., Dor M. 1994. An updated checklist of the fishes of the Red Sea. CLOFRES II. The Israel Academy of Sciences and Humanities, Section of Sciences, Jerusalem: i-xii + 1-120, 2 maps.

Haneda Y., Tsuji F.I. 1971a. Light production in the luminous fishes Photoblepharon and Anomalops from the Banda Islands. Science 173 (3992): 143-145. DOI: 10.1126/science.173.3992.143

Haneda Y., Tsuji F.I. 1971b. The source of light in luminous fishes, Photoblepharon and Anomalops from the Banda Islands. Science Report of the Yokosuka City Museum 18: 18-28.

Harvey E.N. 1922. The production of light by the fishes Photoblepharon and Anomalops. Publications of the Carnegie Institution of Washington 312 (2): 45-60.

Harvey E.N. 1940. Living light. Princeton University Press, Princeton NJ, USA.

Haygood M.G., Tebo B.M., Nealson K.H. 1984. Luminous bacteria of a monocentrid fish (Monocentris japonicus) and two anomalopid fishes (Photoblepharon palpebratus and Kryptophanaron alfredi): Population sizes and growth of the light organ, and rates of release into the seawater. Marine Biology 78 (3): 249-254. DOI: $10.1007 / \mathrm{BF} 00393010$

Hellinger J., Huhn M., Herlitze S. 2017. Bioluminescence in fishes: Diversity and functions. Oceanography and Fisheries Open access Journal 2 (3): e555587. DOI: 10.19080/OFOAJ.2017.02.555587

Ho H.-C., Johnson G.D.2012. Protoblepharon mccoskeri, a new flashlight fish from eastern Taiwan (Teleostei: Anomalopidae). Zootaxa 3479: 77-87. DOI: 10.5281/ zenodo. 212880

Jawad L.A., Al-Mamry J.M., Al-Rasady I.H., AlMamry D.S., Al-Busaidi H.K. 2018. Field atlas of Oman coastal fishes, Arabian Sea. Marine Science and Fisheries Centre, Directorate General of the Fisheries Research, Ministry of Agricultutre and Fisheries, Sultanate of Oman, Muscat, Sultanate of Oman: 1-563.

Johnson G.D., Rosenblatt R.H. 1988. Mechanisms of light organ occlusion in flashlight fishes, family Anomalopidae (Teleostei: Beryciformes), and the evolution of the group. Zoological Journal of the 
Linnean Society 94 (1): 65-96. DOI: 10.1111/j.10963642.1988.tb00882.x

Kailola P.J. 1987. The fishes of Papua New Guinea. A revised and annotated checklist. Volume one. Myxinidae to Synbranchidae. Department of Fisheries and Marine Resources, Port Moresby, Research Bulletin No. 41: i-xxxi + 1-194.

Koeda K., Fujii T., Yoshino T. 2014. [First record of the eyelight fish Photoblepharon palpebratum from Okinawa Island, Japan.] Japanese Journal of Ichthyology 61 (1): 27-31. [In Japanese with English abstract.] DOI: $10.11369 /$ jji.61.27

Kotlâr A.N. [Kotlyar A.N.] 1996. Beriksoobraznye ryby Mirovogo okeana. [Beryciform fishes of the World Ocean.] VNIRO, Moskva, Russia. [In Russian.]

Laboute P., Grandperrin R. 2000. Poissons de NouvelleCalédonie. Éditions Catherine Ledru, Nouméa: 1-520.

Laboute P., Grandperrin R. 2016. Guide des poissons de Nouvelle-Calédonie. Nouvelle édition. Éditions Catherine Ledru, Nouméa: 1-696.

Anonymous [Lacepède B.G.E.] 1832. Oeuvres du Comte de Lacépède, comprenant l'histoire naturelle des quadrupèdes ovipares, des serpents, des poissons et des cétacés; accompanées du portrait de l'auteur et d'environ 400 figures, exécutés pour cette édition par les meilleurs artistes. [Tome 10.] Poissons VI. D. Pillot, Paris: 1-402. DOI: 10.5962/bhl.title.60639

Letourneur Y., Chabanet P., Durville P., Taquet M., Teissier E., Parmentier M., Quéro J.-C., Pothin K. 2004. An updated checklist of the marine fish fauna of Reunion Island, south-western Indian Ocean. Cybium 28 (3): 199-216.

Lieske E., Myers R.F. 2004. Coral reef guide: Red Sea to Gulf of Aden, South Oman: The definitive guide to over 1200 species of underwater life. Collins, London, UK.

Manilo L.G., Bogorodsky S.V. 2003. Taxonomic composition, diversity and distribution of coastal fishes of the Arabian Sea. Journal of Ichthyology $\mathbf{4 3}$ (Suppl. 1): S75-S149.

McCosker J.E. 1977. Flashlight fishes. Scientific American 236 (3): 106-114. DOI: 10.1038/ scientificamerican0377-106

McCosker J.E. 1982. Discovery of Kryptophanaron alfredi (Pisces: Anomalopidae) at San Salvador, Bahamas, with notes on anomalopid light organs. Revista de Biologia Tropical 30 (1): 97-99.

McCosker J.E. 1986. Family No. 129: Anomalopidae. Pp. 413-414. In: Smith M.M., Heemstra P.C. (eds.) Smiths' Sea Fishes. Macmillan South Africa, Johannesburg, South Africa.

McCosker J.E., Lagios M.D. 1975. Les petits peugeots of Grande Comore. Pacific Discovery 28 (5): 1-6.

McCosker J.E., Rosenblatt R.H. 1987. Note on the biology, taxonomy, and distribution of flashlight fishes (Beryciformes: Anomalopidae). Japanese Journal of Ichthyology 34 (2): 157-164. DOI: 10.1007/ BF02912410

Meyer-Rochow V.A. 1976. Some observations on spawning and fecundity in the luminescent fish
Photoblepharon palpebratus. Marine Biology 37 (4): 325-328. DOI: 10.1007/BF00387487

Meyer-Rochow V.A. 1981. Fish tongues-Surface fine structures and ecological considerations. Zoological Journal of the Linnean Society 71 (4): 413-426. DOI: 10.1111/j.1096-3642.1981.tb01137.x

Meyer-Rochow V.A., Baburina V., Smirnov S. 1982. Histological observations on the eyes of the two luminescent fishes Photoblepharon palpebratus (Boddaert) and Anomalops katoptron (Blkr.). Zoologischer Anzeiger B 209 (1-2): 65-72.

Morin J.G., Harrington A., Nealson K., Krieger N., Baldwin T.O., Hastings J.W. 1975. Light for all reasons: Versatility in the behavioral repertoire of the flashlight fish. Science 190 (4209): 74-76. DOI: 10.1126/science. 190.4209 .74

Myers R.F. 1999. Micronesian reef fishes. A comprehensive guide to the coral reef fishes of Micronesia. 3rd revised edn. Coral Graphics, Guam: i-vi + 1-330, pls. 1-192.

Myers R.F., Donaldson T.J. 2003. The fishes of the Mariana Islands. Micronesica 35-36: 598-652.

Nelson J.S. 2006. Fishes of the World. 4th edn. John Wiley and Sons, Hoboken NJ, USA.

Ogilby J.D. 1890. Re-description of Anomalops palpebratus (Bodd.). Records of the Australian Museum 1 (3): 69-71. DOI: 10.3853/j.00671975.1.1890.1229

Paxton J.R., Gates J.E., Bray D.J., Hoese D.F. 2006. Anomalopidae. Flashlight fishes. Pp. 763-764. In: Hoese D.F., Bray D.J., Paxton J.R., Allen G.R. (eds.): Zoological Catalogue of Australia. Volume 35. Fishes. Parts 1-3. CSIRO Publishing, Collingwood VIC, Australia.

Paxton J.R., Johnson G.D. 1999. Family Anomalopidae. Pp. 2212-2213. In: Carpenter K.E., Niem V.H. (eds.) Species identification guide for fisheries purposes. The living marine resources of the western central Pacific. Bony fishes part 2. Volume 4 (Mugilidae to Carangidae). FAO, Rome.

Paxton J.R., Johnson G.D. 2000. Family Anomalopidae. P. 601. In: Randall J.E., Lim K.K.P. (eds.) A checklist of the fishes of the South China Sea. Raffles Bulletin of Zoology 2000 (Suppl. 8): 569-667.

Randall J.E. 1983. Red Sea reef fishes. Immel Publishing, London, UK: 1-192.

Randall J.E. 1986. 106 new records of fishes from the Marshall Islands. Bulletin of Marine Science 38 (1): 170-252.

Randall J.E. 1995. Coastal fishes of Oman. University of Hawai'i Press, Honolulu HI, USA: 439 pp.

Randall J.E. 2005. Reef and shore fishes of the South Pacific. New Caledonia to Tahiti and the Pitcairn Islands. University of Hawai'i Press, Honolulu HI, USA: i-xii + 1-707.

Randall J.E., Allen G.R., Steene R.C. 1997. Fishes of the Great Barrier Reef and Coral Sea. 2nd, revised edn. Crawford House Press, Bathurst NSW, Australia: i-xx $+1-557$, pls. $1-7$. 
Randall J.E., Anderson R.C. 1993. Annotated checklist of the epipelagic and shore fishes of the Maldive Islands. Ichthyological Bulletin of the J.L.B. Smith Institute of Ichthyology 59: 1-47.

Randall J.E., Randall H.A. 1987. Annotated checklist of the fished of Enewetak Atoll and other Marshall islands. Pp. 289-324. In: Devaney D.M., Reese E.S., Burch B.L., Helfrich P. (eds.) The natural history of Enewetak Atoll. Volume II. Biogeography and systematics. US Department of Energy, Oak Ridge TN, USA.

Reuvens C.L. 1897. [Note IX.] On Anomalops palpebratus (Bodd.). Notes from the Leyden Museum 19 (1-2): 127-128.

Rivaton J., Fourmanoir P., Bourret P., Kulbicki M. 1990. Catalogue des poissons de Nouvelle-Calédonie. ORSTOM, Nouméa, Sciences de la Mer, Biologie Marine, Document de Travail: 1-170.

Rosenblatt R.H., Johnson G.D. 1991. Parmops coruscans, a new genus and species of flashlight fish (Beryciformes: Anomalopidae) from the South Pacific. Proceedings of the Biological Society of Washington 104 (2): 328-334.

Schwarzhans W. 1980. Die tertiäre Teleosteer-Fauna Neuseelands, rekonstruiert anhand von Otolithen. Berliner Geowissenschaftliche Abhandlungen A 26: 1-211, 2 maps.

Steche O. 1909. Die Leuchtorgane von Anomalops katoptron und Photoblepharon palpebratus, zwei Oberflächenfischen aus dem Malaiischen Archipel. Ein Beitrag zur Morphologie und Physiologie der Leuchtorgane derFische. Zeitschrift fürWissenschaftliche Zoologie 93 (3): 349-408, pls. 19-21.
Tan H.H., Naruse T., Fujita Y., Tan S.K. 2014. Observations on the fauna from submarine and associated anchialine caves in Christmas Island, Indian Ocean territory, Australia. Raffles Bulletin of Zoology 2014 (Suppl. 30): 406-418.

Vorderman A.G. 1900. Twee lichtgevende visschen van Banda. Ikan lěvéri batoe (Heterophthalmus palpebratus Lac.) en ikan lěvéri ajer (Heterophthalmus katoptron Blkr.?) [Two luminous fish from Banda. Ikan lěvéri batoe (Heterophthalmus palpebratus Lac.) and ikan lěvéri ajer (Heterophthalmus katoptron Blkr.?).] Natuurkundig Tijdschrift voor Nederlandsch-Indië 59 (10 Ser. Part 3): 72-77. [In Dutch.]

Weber M. 1902. Introduction et description de l'expédition. In: Siboga-Expeditie. Uitkomsten op zoologisch, botanisch, ocenographisch en geologisch gebied verzameld in nederlandsch Oost-Indië 18991900 aan boord H. M. Siboga onder commando van Luitenant ter zee 1e Kl. G. F. Tydeman. No. 1 (livr. 3). E. J. Brill, Leiden: 1-159, 1 map.

Weber M. 1913. Die Fische der Siboga-Expedition. E. J. Brill, Leiden: i-xii + 1-710, pls. 1-12.

Weber M., de Beaufort L.F. 1929. The fishes of the Indo-Australian Archipelago. V. Anacanthini, Allotriognathi, Heterostomata, Berycomorphi, Percomorphi: families Kuhliidae, Apogonidae, Plesiopidae, Pseudoplesiopidae, Priacanthidae, Centropomidae. E. J. Brill, Leiden: i-xiv + 1-458.

Zehren S.J. 1979. The comparative osteology and phylogeny of the Beryciformes (Pisces: Teleostei). Evolutionary Monographs 1: 1-389.

Received: 3 August 2018

Accepted: 2 October 2018

Published electronically: 15 March 2019 